\title{
KATILIM BANKALARINDA İNTERNET BANKACILIĞI: ELAZIĞ İLİ ÖRNEĞİ
}

\author{
Internet Banking in Participation Banks: The Case of Elazig \\ Özcan DEMIR ${ }^{1}$ \\ Yavuz ATLI ${ }^{2}$
}

\begin{abstract}
ÖZET
Bankacılık sektöründe son yıllarda büyük bir gelişme gösteren katılım bankacılığı özellikle faizle işlem yapmak istemeyen muhafazakar kesimin tercih sebebi olmuştur. Katılım bankacılığı pek çok enstrümanıyla bilinen bankacılık yapısının özelliklerini taşımakla beraber, sistem İslam hukukuna yer alan kar- zarar ortaklığı yöntemiyle fon toplamak ve fon kullandırmaktadır.

Bu çalışmada katııım bankalarını tercih eden müşterilerin katılım bankacılığı hizmetlerinden elektronik iletişim kanalları ile yararlanma düzeyleri tespit edilmeye çalışılmıştır. Araştırmanın evrenini, Elazığ ilinde faaliyet gösteren Katılım Bankaları müş̧erileri oluşturmaktadır. Araştırmada nicel araştırma yöntemi kullanılmış ve veriler anket tekniği ile toplanmıştır. Elde edilen veriler SPSS 20 programında analiz edilmiştir. Araştırma sonucunda Katılım bankacılığ 1 müşterilerinin internet bankacıllı̆ı̆ndan yararlanma düzeyleri ve bu yararlanma düzeylerini etkileyen müşteri demografik özelliklere göre farklıllı gösterip göstermediği tespit edilmeye çalışılmışıır. Katılım Bankalarında internet bankacılığı ile ilgili elde edilen çeşitli bulgularda; Katılım Bankalarının Mevduat Bankalarına göre daha kuralcı ve daha güvenli bir bankacılık modeli geliştirmeye çalıştıkları ortaya konulmaktadır. Katılım Bankalarının internet bankacılığını güvenli bir şekilde kullanan müşteriler zaman sınırlaması olmadan birçok bankacılık işlemini gerçekleştirdiği için tercih edilmelerinde de önemli bir etken olarak görünmektedir.
\end{abstract}

Anahtar Kelimeler: İnternet Bankacılığı, Katılım Bankaları.

\section{ABSTRACT}

Participaiton banking has shown a big improvement in the banking sector in recent years, particularly conservative people who do not want to deal with interests chose their services. Along with the well known instruments of standard banking systems, participation banking employs profit/loss participation investment to raise and utilize funds which is legal in Islamic law.

In this study we tried to find out the usage levels of electronic communication channels to get participation banking services by customers who chose this kind of banking. The field of the study includes participaion banking customers in Elazığ. In the study, quantitative research techniques were used and the data was collected through surveys. The data was analysed with the SPSS 20 programme. We tried to find out the usage levels of internet banking by participation banking customers and to find out whether these usage levels differed by demographics of the customers. Some results about internet banking in participation banks show that participaion banks try to improve a more secure and normative banking model than deposit banks. The secure internet banking systems of participation banks enable their customers to do many banking processes at any time they like and this seems to be an important reason for them to chose participation banking.

Keywords: Internet Banking, Participation Banks.

\section{GİRISS}

Son yıllarda bilgi ve iletişim teknolojilerinde yaşanan hızlı değişmeler ekonomik, toplumsal ve siyasal doğrultuda çok boyutlu değişim-dönüşüm sürecini başlatmış, toplumların tüm kesimlerinde, bilgisayar kullanımı çağın gereği olduğunu ortaya çıkarmaktadır. Küreselleşen ekonomilerde, rekabet üstünlüğü ve toplumsal refahın sağlanmasında bilgi ve iletişim teknolojileri stratejik bir önem kazanmıştır. $\mathrm{Bu}$ teknolojilerin başında internet gelmektedir. İnternet, iletişim sistemine

\footnotetext{
${ }^{1}$ Yrd.Doç. Dr., Fırat Üniversitesi, İktisadi ve İdari Bilimler Fakültesi, İşletme Bölümü, E-posta odemir@firat.edu.tr

${ }^{2}$ Öğr.Gör.,Fırat Üniversitesi, Kovancılar MYO, İşletme Programı, E-posta yatli@,firat.edu.tr
} 
(Modem veya Lan bağlantısı) sahip çok sayıdaki bilgisayarın birbiri ile iletişim kurmasını sağlayan ağ sistemidir. Çeşitli kaynaklarda "Ağların ağı" olarak adlandırılan internet, çok sayıda haberleşme ağının birleşmesiyle oluşan sürekli olarak gelişen bir sistem olarak, ifade edilebilir (Aslan,1998:5).

İnternet kavramının öne çıkması ve hızla yayılması birçok sektörü olduğu gibi bankacılık sektörünü de yakından etkileyerek müşterilerin artık banka şubelerine gitmeden bir çok işlemi yapabilmelerine olanak tanımaktadır. Çağımıza, ismini veren bilgi ve teknoloji kavramlarının en önemli unsurlarından biri olan internetin bankacılık sektöründe büyük bir yerinin olduğu kabul edilen bir realitedir.

Çalışmada internet bankacılığının kullanım düzeyini etkileyen müşteri demografik faktörlerinin ve fiziki şartların Katılım Bankalarında internet bankacılığını nasıl etkilediği ortaya konulmaya çalışılmıştır.

\section{2. İNTERNET ve KATILIM BANKACILIĞI KAVRAMI}

\subsection{INTERNET KAVRAMI}

İnternet, iletişim sistemine (Modem veya Lan bağlantısı) sahip çok sayıdaki bilgisayarın birbiri ile iletişim kurmasını sağlayan ağ sistemidir. Çeşitli kaynaklarda "Ağların ağı" olarak adlandırılan internet, çok sayıda haberleşme ağının birleşmesiyle oluşan sürekli olarak gelişen bir sistem olarak, ifade edilebilir (Aslan, 1998:5).

Dünyada birçok kesimin rahatlıkla ulaşabileceği boyuttaki bu küresel haberleşme ağı; bilgi kaynağı ve temel iş aracı olarak çok amaçlı olarak kullanılmaktadır. İnternet ortamına girişin gerektirdiği telefon hattı, bilgisayar, modem v.b donanımlar belli bir gelir seviyesindeki insanlara hitap etmektedir. Ülkelerin milli gelir düzeyleri ile insanların internet kullanımı oranı arasında doğru bir orantı bulunmaktadır. Yapılan bir araştırmada; hane halkı gelirindeki her bin dolarlık artış, bilgisayarlaşma oranı \%7 artırmaktadır (İnce, 1999:4).

\subsection{INTERNETIN BANKACILIK SEKTÖRÜNDEKİ ETKILERİ}

Dünya'daki bilgi teknolojilerinin hızlı gelişimi ve değişimi ile birlikte ortaya çıkan internet bütün sektörleri etkilediği gibi yeni sektörlerin de ortaya çıkmasına neden olmuştur. Sanayi, sağlık, tarım, eğitim vs. gibi birçok sektörün internete entegrasyonu sağlanarak pazarlama anlayışının değişmesine yol açmaktadır.

Bankacılık hakkında ilk çalışmalar M.Ö. 3500 yıllarında Sümer ve Babil uygarlıklarında rastlanmaktadır. M.Ö. 2123-2081 tarihleri arasında Babil imparatoru Hammurabi Kanunları'nda tapınaklarda yapılacak borç verme işlemleri, borcun tahsil yöntemleri, alınacak faiz oranları ile rehin, ipotek ve kefalet şekillerini düzenlendiği çeşitli hükümler bulunmaktadır (Tarlan, 1986:29).

19. yüzyıla kadar bankalar kendi kaynakları veri topladıkları mevduat ile işlemlerini sürdürürken 19. yüzyılın başından itibaren farklı bankacilık enstrümanları ile ekonomilerdeki yerlerini güçlendirmeye devam etmişlerdir. Küresel anlamda 1930'larda yaşanan "Büyük Ekonomik Buhran" sonrasında yaşanan II. Dünya Savaş1 ve 1970'lerdeki petrol krizi gibi Dünya'nın ekonomik yapısını değiştiren olaylar bankaların finansal yapısını büyük ölçüde etkilemiş ve çeşitli sıkıntılarla karşılaşılması sektörün yeni enstrümanlar, yeni finansman tekniklerini geliştirmesine yol açmış sonraki aşamada bilgisayar teknolojileri kullanılmaya başlanmıştır. Gelişmiş ülkelerdeki serbest piyasa ekonomisinin uygulanması nedeniyle global bankacılık gelişirken, ülkemizde ancak 1980'lerden sonra küresel bankacılık anlayışı ile tanışmıştır.1980'li yıllarda Türkiye'nin dışa doğru açılma politikaları çerçevesinde piyasaya giren çok sayıda yabancı banka rekabeti artırmış, diğer yönden faizlerin ve döviz tevdiat hesaplarının serbest bırakılması, Türkiye'deki bankacılığın hizmet yapısının ve anlayışının değişmesine neden olmuştur (Çınar ve Erciş, 1993:6).

Bankaların, 1950'li yıllardan sonra dünyada yaşanan iç ve dış savaşların bitmesi ve ülkelerin kendilerini teknoloji ve ticaret alanında geliştirmeye başlamalarına neden olmuştur. Teknolojide 
yaşanan bu gelişme elektronik çağ denilen yeni bir çağın doğmasına, bu da sektörler içinde en fazla bankacılık sektörünü etkilemiş olup, sektörde farklı bir sistemin oluşturulmasına neden olmuştur (Işkıı, 2010:26).

Ekonomik sistemin doğrudan içinde bulunan bankalar, piyasadaki varlıklarını sürdürebilmek ve artan rekabet ortamında rekabet avantajı yaratabilmek için çeşitli teknolojik yatırımları gerçekleştirmek zorunda kalmışlardır. Hızlı teknolojik gelişme ve dünya piyasalarının küresel hale gelmesi bilgisayar teknolojilerinin yoğun kullanıldığı sektörlerin başında bankacılık sektörünün gelmesine neden olmuştur. Dolayısıyla bilgisayar teknolojilerinin bankacılık sektöründe kullanılması çok eskilere dayanmakta ve bankalar bu anlamda ilk kullanıcılardan sayılabilirler (Saka,2001:1).

Yaklaşık 20 yıl öncesine kadar banka şubesine gitmeden bir bankacılık işlemi yapmak mümkün değilken, bugün bütün bankacılık işlemlerini bir banka şubesine gitmeden yapmak mümkün hale gelmiştir. Teknolojik gelişmelerin bankacılık sistemini getirdiği nokta, hiç şubesi olmayan, yalnızca internet ve diğer alternatif dağıtım kanalları üzerinden çalışan bankalardır. Teknolojik gelişmeler bir taraftan yeni kanalları ortaya çıkarırken, diğer taraftan eski kanalların da işlevlerini artırmaktadır. Daha önce sadece bakiye görüntüleme ve para çekme için kullanılan ATM'ler, yeni teknolojilerle birlikte para yatırma, fatura tahsilatı, bozuk para iadesi gibi işlemleri yapabilir konuma gelmiştir (Öztürk, 2009:99).

Bilgisayar teknolojilerinde yaşanan hızlı değişim ve bunların bankalara adaptasyonu, ülkeler arasındaki ticari ve hukuki korumaların serbestleşmesi, yeni finansal ürünlerin kullanılması ve elektronik ticaret ile ilgili çeşitli yasal düzenlemelerin hayata geçirilmesi sektörde daha hızlı adaptasyonu sağlamıştır. Sektörün düşük maliyetle daha fazla kullanıcıya daha etkin bir şekilde yeni alternatif dağııım kanallarıyla ulaşmasını etkin kılmıştır. Bu da bankaların müşterileri ile direk, daha kolay, daha hızlı ve daha az maliyetle iletişim kurmalarına imkan tanımıştır (Akgeyik, 2008:28).

Bankaların 90'lardan önce en önemli rekabet stratejisi yaygın şube ağı iken son yirmi yıldaki teknolojik gelişmeler ile elektronik ortamda hizmet verilebilirliği yani bilgisayar teknolojilerinin banka sistemine adaptasyonu, rekabette önemli bir üstünlük unsuru haline gelmiştir. Müssterilerin elektronik bankacılık ile 7/24 hizmet alabilmesi, internetin yaygınlaşması ile kolay ulaşılabilirlik, daha az maliyet, daha az zaman gibi birçok faktör nedeniyle çok hızlı bir şekilde elektronik bankacılık tercihi artmıştır.

Ülkemizde ilk internet şubesi 1998 yılında Türkiye İş Bankası tarafından devreye sokulmuştur. Ardından Garanti Bankası, Osmanlı Bankası ve Pamukbank da aynı yıl içerisinde internet üzerinden bankacılık hizmeti sunmaya başlamıştır. Günümüzde ise bütün bankaların internet şubesi bulunmaktadır.

Türkiye Bankalar Birliği (TBB)'nin 2011 Haziranda yayımlanan rapora göre Türkiye'de İnternet bankacılığ 1 yapmak üzere sistemde kayıtlı olan ve en az bir kez giriş işlemi yapmış toplam bireysel müşteri sayıs1, Haziran 2011 itibariyle 16,7 milyon kişiye ulaşmıştır. Ancak, bu müşterilerin aktif kullanıcı olarak kabul edilen Nisan - Haziran 2011 döneminde en az bir kez internet bankacılığı giriş işlemi yapmış bireysel internet bankacılığı kullanıc1 sayısı 6,7 milyon olarak gerçekleşmiştir. Bu rakamlar kurumsal kullanıcıları da dahil edince sırasıyla 18,5 milyon ve 7,5 milyon olarak gerçekleşti. İnternet bankacılığını kullanan aktif müşteri sayısı son bir yılda 1,3 milyon kişi artmışır. Türkiye' de 25 bankanın internet bankacılığı şubesi bulunmaktadır, bu istatistiklere Türkiye'de sayısı 4 olan katılım bankalarının istatistikleri dahil değildir. (http://www.tbb.org).

\subsection{KATILIM BANKACILIĞI KAVRAMI}

Modern anlamda faizsiz bankacılığın ilk örneği 1963 yılında Mısır'da Mit- Ghamr'da kurulmuştur. Bunu takip eden y1llarda özellikle Körfez ülkeleri başta olmak üzere bütün dünyada pek çok faizsiz banka tesis edilmiştir (Aktepe, 2010:71). 
Faizsiz bankacılık, Ortadoğu'da petrol gelirlerindeki artış ile meydana gelen yeni zenginlik ve dünya nüfusunun \%30'una denk gelen Müslüman nüfusun, faizsiz nitelikteki finans ürünlerine olan ilgisi sonucunda, en hızlı gelişen sektör durumundadır. Uluslararası Finans Forumu'na göre faizsiz bankaların mevcutları y1llık \%15 oranında büyürken faizsiz fonlar ise yıllık ortalama $\% 40$ oranında büyümektedir (www.tkbb.org.tr).

Katılım Bankaları, kar ve zarara katılma esasına göre çalışan kuruluşlar olarak İslam'ın yasaklamış olduğu faiz kavramından tamamen uzak bir şekilde finansal işlevleri yerine getiren kurumlardır. Doğal olarak finansal sistemin içerisinde olup da faiz kavramında uzak bir şekilde faaliyetleri yerine getirmesi bir çok sıkıntıya ve kısıtlı enstrümana sahip olmasına neden olmaktadır. Söz konusu kuruluşlar İslami temellere dayalı olmaları nedeniyle "İslami Bankacılık" veya "Faizsiz Bankacılık" olarak da adlandırılmaktadır. Ülkemizde 15.12.1983 tarihinde Bakanlar Kurulu'nca kabul edilen Kanun Hükmünde Kararname'de belirtildiği üzere kar ve zarara katılma esasına göre çalışan bu bankacılık türü 2006 yılına kadar "Özel Finans Kurumu" adıyla faaliyetlerini devam ettirirken 2006 yılından sonra "Katılım Bankaları" adılla halen günümüzde faaliyetlerini devam ettiren kuruluşlardır.

Özellikle dini hassasiyetleri bulunan müşterilerin tercih ettiği katılım bankalarının, gerek ülkemizdeki faaliyetlerine 1985 sonrasında başlamaları, gerekse faizsiz bankacılığın getirdiği kısıtlamalar nedeniyle toplam bankacılık içerisindeki payları, 2011 yılı sonu itibariyle \%5.1 gibi çok düşük bir rakamlarda seyretmektedir (www.tkbb.org.tr).

Dünya'da olduğu gibi Türkiye'de de toplumun bir kısmı, faizi kapsayan işlemlerden dolayısıyla faiz esasına göre çalışan bankalardan uzak durmaktadırlar. Dolayısıyla faizsiz bankacılığın olmadığı ekonomilerde bu tür hassasiyetleri bulunan fon sahiplerinin fonları genel ekonomi dışında kalacak ve hem tasarruf sahipleri için hem de yatırım sahipleri için çeşitli kayıplara neden olacaktır. Bu tür müşterilerin ekonomiye kazandırılması başta İslam ülkeleri olmak üzere bir çok ülkeyi özellikle ikinci dünya savaşından sonra harekete geçirerek faiz yerine kar/zarar esasına dayanan katılım bankalarının kurulmasına neden olmuştur (Aras ve Öztürk, 2011:3).

\subsubsection{KATILIM BANKALARININ DAYANDIĞI İLKELER}

Katılım bankalarının başlıca belirgin özellikleri; faizsiz bankacılık yapması, aracı kurum olması, güven kurumu olması ve banka niteliğinin olması şeklinde sınıflandırılabilir.

\subsubsection{Faizsiz Bankacılık Faaliyeti Yapması}

Faiz belirli bir miktarda anaparanın belirli bir vadede, belirli bir oranda elde ettiği getiri olarak tanımlanabilir. Yani borç verenin vade ve oranı belirlediği, alanın da kabul ettiği bir uzlaşma söz konusudur. Faiz uygulamasında her iki tarafta ne kadar faiz verilip-alınacağı konusu net bir şekilde bilmektedir.

Katılım bankalarının en ayırt edici özelliği çalışmalarında faize yer vermemeleridir. Yani, sağladıkları kaynaklara faiz ödemezler; kullandırdıkları kaynak için müşterilerinden faiz tahsil etmezler. Zaten kuruluşlarının gerekçesi de, faizli işlemlere dini görüşü gereği yer vermeyen insanlara ve bu tur insanların şirketlerine hizmet etmektir. İslamiyet sermayenin üretim faktörlerinden biri olduğunu ve bir maliyeti olduğunu kabul eder. Ancak bu faktörün önceden belirlenmiş bir karşl1ık, yani faiz talep etmesini reddeder. Bir diğer ifadeyle, parayla para kazanmak yasaktır (Uslu, 2004:45).

Faizsiz çalışma esasına dayalı kar payı taraflarca belirlenen vadeye kadar ticari ve sınai bir ekonomik faaliyette kullanılan anaparanın elde ettiği karın vadesi geldiğinde anlaşılan oranda taraflara dağıtılan kısmıdır. Tasarruf sahiplerinin katılım bankalarına yatırdığ 1 para, bu kurumlarca sağlam ve verimli projelerde kullanılmak üzere yatırımcılara belirlenen vade ve piyasada oluşan kar oranları ile kullandırılır. Vade sonunda yatırımcidan elde edilen karın \%80 k1smı tasarruf sahibine \%20 l1k kısmı ise banka kendisine alır. Burada dikkat edilmesi gereken nokta vade 
sonunda yatırımcının ne kadar kar ödeyeceği tasarruf sahibinin ise ne kadar kar alacağı belli değildir. Keza yapılan bu işlem sonucunda yatırımcı zarar da edebilir, bu da bankanın kullandırmış olduğu fonun batmasına ve hem bankanın hem de tasarruf sahibinin zarar etmesine neden olacaktır. Tabi doğrudan tasarruf sahiplerinden alınan fon numaralandırılarak yatırımcıya kullandırılması söz konusu değildir bu nedenle yatırımcının zarar etmesi katılım bankasının oluşturduğu fon havuzunun karlılığını düşmesine neden olacaktır.

Vade farkı ile faiz arasındaki fark hukuken önemli bir fark olmamakla beraber, inanç itibariyle önemli olabilir. Zira birincisinde mal ticaretinden elde edilen bir kazanç, ikincisinde para ticaretinden elde edilen bir kazanç vardır (Battal, 2004: 228). Dikkat edilmesi gereken önemli nokta inançları gereği tasarruflarını ve kullanacakları fonları faizli bankacılık sisteminde değerlendirmek istemeyen tarafların bu sisteme dahil edilmesidir.

\subsubsection{Aracı Kurum Niteliğine Sahip Olması}

Katılım Bankaları finansal sitemde tasarruf sahiplerinin tasarruflarını toplayarak ihtiyacı olan ekonomik birimlere dağıtılması ile ekonomik sistemde aracı kurum rolünü üstlenmektedir. Mali piyasalarda tasarruf sahibi ödünç verenler ile ödünç alanlar arasında geçiş mekanizmasını oluşturan kurumlar olduğuna göre katılım bankaları da banka dışı finansal aracı kabul edilmelidir (Parasız, 1992:75).

5411 sayılı Bankacılık Kanunu'na göre katılım bankaları banka dışı finansal aracı olmaktan çıkmışıır. Daha önceleri özel finans kurumu olarak ifade edilen ve banka kelimesinin kullanılmasından kaçınılan katılım bankaları yeni kanun ile birlikte bir bankacılık türü olarak ifade edilmişlerdir. Mali piyasalarda tasarruf sahibi ödünç verenlerle ödünç alan harcayıcılar arasında geçiş mekanizmasını oluşturan kurumlar olduklarından katılım bankaları aracı kurumlardır (Şimşek, 2006:17).

\subsubsection{Güven Kurumu Niteliğine Sahip Olması}

Özel izin ve imtiyazla çalışmaları, özel denetim usullerine tabi olmaları, devletin müdahalesine açık olmaları, özel ağırlaştırılmış sorumluluk kurallarına tabi olmaları ve özellikle mevduat hesabı sahibi müşteriler karşısındaki itibarları bankaların güven kurumu olarak anılmalarının başlıca sebepleridir (Battal, 1999: 7).

Bankalar müşterilerin birçoğu tarafından güvenilen kurumlar olarak görülmektedir. $\mathrm{Bu}$ güvenin en büyük nedeni devletin tasarruf sahiplerine uyguladığı güvencedir. Bunun dışında özel izin ve imtiyazla çalışmaları, özel denetim usullerine tabi olmaları, devletin müdahalesine açık olmaları, özel ağırlaştırılmış sorumluluk kurallarına tabi olmaları gibi birçok neden gösterilebilmektedir.

Katılım Bankaları da aynı özelliklere sahiptir denilebilinir. Bankalar mevduata faiz garantisi verirken katılım bankaları her ne kadar topladıkları fonlara böyle bir garanti vermese de, sadece elde edilmesi halinde kar payı değil, zarar halinde ise zarara da kanunlar gereği iştirak etmeyi vaat etmektedir. Ayrıca, katılım bankalarının da diğer bankalar gibi yatırımcılara kullandıracakları fon için çeşitli teminatlar alması bankanın riskini azaltarak tasarruf sahiplerinin güven duymasına neden olmuştur.

Ülkemizde özellikle 2005 yılından sonra yapılan hukuki düzenlemeler ile katılım bankalarının da normal banka statüsünde değerlendirilmesi hem tasarruf sahipleri için hem yatırımcılar için aynı cezai müeyyidelere tabi tutulması güven olgusunun karşılıklı oluşmasına neden olmuştur (Atl1, 2013,78)

\subsubsection{Banka Niteliğine Sahip Olması}

Önceki bölümlerde de bahsettiğimiz gibi ülkemizde 2005 yılından sonra katılım bankalarının da 5411 sayılı Bankacılık Kanuna tabi olması, banka niteliği kazanmasına neden olmuştur. 5411 
sayılı Bankacılık Kanunu'nda 3 tür banka vardır. Bunlar; Ticari Bankalar, Kalkınma ve Yatırım Bankaları, ve Katılım Bankalarıdır.

\section{ARAŞTIRMA BULGULARI}

\subsection{ARAŞTIRMANIN YÖNTEMI}

Araştırmada, katılım bankaları müşterilerinin internet bankacılığına yaklaşımlarının ölçülmesi üzerine ampirik bir çalışma olup müşterilerin düşüncelerini saptamak için de anket yöntemi kullanılmıştır. Bu yöntemin kullanılmasının nedeni, deneklerin sunulan hizmeti algılamalarının ve onların beklentilerinin belirlenmesinde, diğere yöntemlere oranla daha uygun cevap alma olasılığının yüksek olması ve gerektiğinde deneğe gereken açıklamaların yapılabilmesinin sağlanmasıdır.

Geçerli bir anket formu düzenleyebilmek için ilk olarak, kapsamlı bir mevcut yazın taraması gerçekleştirilmiş ve araştırma sonucunda konu hakkında yazında yer alan yerli ve yabancı çalışmalar anket formunun ortaya çıkmasında önemli rol oynamışlardır. Tarama sonrasında, bir anket taslağı oluşturulmuş, hazırlanan anket taslağı, araştırmacının bankacılık sektöründe görev yapan arkadaşları aracılığıyla 20 katılım bankası müşterisine anket formları doldurtularak anketlerin ön testleri yapılmıştır. Anket formu 3 bölümden oluşup, ilk bölümde deneklerin demografik özelliklerine ilişkin sorular, ikinci bölümde Katılım Bankaları ile müşterileri arasında en fazla kullanılan iletişim teknikleri ile ilgili sorular, üçüncü son bölümde ise Katılım Bankalarındaki pazarlama karması elemanlarının (ürün, fiyat, tutundurma, dağıtım, hedef kitle, süreç, fiziksel belirti) incelenmesi ile ilgili sorular bulunmaktadır.

Anket formumuzu cevaplayıcıların katılım bankaları müşterileri olması nedeniyle basımı gerçekleşen 450 adet anket formu katılım bankaları şubeleri ile yaptığımız görüşmelerde belirlenen müşterilere anket formu dağıtımı yapılmıştır. Bazı banka müşterilerinin anket formunu doldurmak istememesi bazı banka müşterilerinin anket formundaki kimi soruları cevaplandırmak istememesi nedenlerle, 384 adet anket formu cevaplayıcılardan alınmıştır. Anket formlarının geri dönüş oranı $\% 84$ olarak belirlenmiştir.

\subsection{EVREN VE ÖRNEKLEM}

Evren, araştırılacak olan birimlerin tamamıdır. Örnekleme çerçevesi ise, ana kütleyi oluşturan birimlerin listesidir. Örnek, ana kütleyi en iyi temsil eden ve belli bir yönteme göre ana kütleden seçilen alt gruptur (Nakip, 2003:175). Örnekleme türleri ile ilgili olarak çeşitli sınıflandırmaların olduğu görülebilir. Örnekleme türlerinin olasılıklı ve olasılıksız olmak üzere iki şekilde ele alınarak sınıflandırmanın yaygın olarak kullanıldığı söylenebilir.

Olasılıklı örnekleme, evreni oluşturan birimlerin hepsine eşit seçilebilme şansının verildiği örnekleme türüdür. Olasılıklı örnekleme türleri; basit tesadüfi örnekleme, sistematik örnekleme, tabakalı örnekleme ve küme örnekleme olarak kendi arasında ayrılmaktadır (Yazıcıoğlu ve Erdoğan, 2004:65).

Basit tesadüfi örneklemede evreni oluşturan her elemanın örneğe girme şansı eşittir. Dolayısıyla hesaplamalarda da her elemana verilecek ağırlık aynıdır. Araştırmada basit tesadüfi örnekleme yöntemi seçilmiştir.

Araştırmanın evreni, Albaraka Türk Katılım Bankası, Asya Finans Katılım Bankası, Türkiye Finans Katılım Bankası ve Kuveyt Türk Katılım Bankalarının Elazı̆g ilinde ikamet eden müşterileridir. Bu dört bankanın Elazığ ilinde bulunan müşteri sayılarını öğrenebilmek için banka şubeleri ile yapılan görüşmelerde; Asya Finans Katılım Bankası Elazığ şubesinin 25.000 adet aktif müşterisinin olduğunu bunun 2.600 kişinin internet bankacılığını kullandığı, Albaraka Türk Katılım Bankası Elazığ şubesinin toplam 5.800 adet aktif müşterisi olduğunu bunun 950 kişinin internet bankacılığını kullandığını, Türkiye Finans Katılım Bankası Elazığ şubesinin toplam 10.500 adet aktif müşterisi olduğunu bunun 1.750 kişinin internet bankacılığını kullandığını, Kuveyt Türk 
Katılım Bankası Elazı̆ şubesinin toplam 8.000 adet aktif müşterisi olduğunu bunun 1.400 kişinin internet bankacılı̆̆ını kullandığı, bilgisine ulaşılmıştır. Bu bilgiler 1şığında evrenimiz 49.500 kişidir. Yine Katılım Bankaları yetkilileri ile yapılan görüşmelerde bir katılım bankası müşterilerinin \%20 sinin diğer 3 katılım bankası ile de aktif olarak çalıştığı bilgisine ulaşılmıştır. Dolayısıyla yalnız Asya Finans Katılım Bankası müşterisi 25.000- $(25.000 * \% 20)=20.000$ kişi, yalnız Albaraka Türk Katılım Bankası müşterisi 5.800-(5.800*\%20)= 5.220 kişi, yalnız Türkiye Finans Katılım Bankası müşterisi 10.500-(10.500*\%20) = 9.450 kişi, yalnız Kuveyt Türk Katılım Bankas1 müşterisi $8.000-(8.000 * \% 20)=6.400$ kişidir. Ortak müşterilerinin en büyügüne sadece rakamlarına eklediğimizde evren büyüklügümüz, 46.070 kişi olarak belirlenmiştir. 50.000 kişilik bir evren büyüklüğünde $\% 5$ güven aralığında 381 örneklem, evreni temsil edecektir. Araştırmada geri dönen anket sayısının 384 olması, olasılıklı basit tesadüfi örneklem yönteminde $\% 5$ güven aralığında evreni temsil edecektir (Yazıcıŏ̆lu ve Erdoğan, 2004:65).

\subsection{ARAŞTIRMANIN HIPOTEZLERİ}

H1- Katılım Bankalarında web sitesinin güvenirliği ile müşterilerin iletişim kanalı seçimi arasında istatistiksel bir bağlantı vardır.

H2- Katılım Bankalarında 7/24 hizmet alınması müşterilerin iletişim kanalı seçiminde istatistiksel olarak anlamlı ilişki vardır.

H3- Katılım Bankalarında İnternet Bankacılığında yapılan işlemin düşük maliyetli olması ile müşterilerin cinsiyeti arasında istatistiksel bir ilişki vardır.

H4- Katılım Bankalarında web sitesinin yüklenme hızı ile müşterilerin eğitim düzeyi arasında istatistiksel bir bağlantı vardır.

H5- Katılım Bankalarında web sitesinin sürekli yenilenmesi ile müşterilerin eğitim düzeyi arasında istatistiksel olarak anlamlı bir ilişki vardır.

\section{4. ÖLÇEĞİN GÜVENİRLİĞİ}

Katılım Bankacılığında 7P Ölçeğinin (KB7P) güvenirlik çalışması Cronbach Alpha güvenirliği, madde toplam korelasyonu ve alt $\% 27-u ̈ s t \% 27$ çeyrekler $t$ testi yöntemleri ile yapılmıştır. Cronbach Alpha güvenirliği elde edilen test puanları arasındaki iç tutarlı̆̆ incelemek amacıyla kullanılır. Test için hesaplanan güvenirlik katsayısının 0,70 ve daha yüksek olması test puanlarının güvenirliği için genel olarak yeterli görülmektedir (Büyüköztürk, 2011:171).

Madde toplam korelasyonu, test maddelerinden alınan puanlar ile testin toplam puan arasındaki ilişkiyi açıklar. Madde-toplam korelasyonunun pozitif ve yüksek olması, maddelerin benzer davranışları örneklediğini gösterir ve testin iç tutarlığının yüksek olduğunu gösterir. Madde toplam korelasyonu 0,30 ve daha yüksek olan maddelerin bireyleri iyi derecede ayırt ettiği, 0,20 0,30 arasında kalan maddelerin zorunlu görülmesi durumunda teste alınabileceği veya maddenin düzeltilmesi gerektiği kabul edilir (Büyüköztürk, 2011:171).

Alt ve üst çeyrekler $t$ testi testin toplam puanlarına göre oluşturulan alt\%27 ve üst\%27'lik grupların madde ortalama puanları arasındaki farkların ilişkisiz t-testi kullanılarak sınanmasıdır. Gruplar arasında istendik yönde gözlenen farkların anlamlı çıkması, testin iç tutarlığının bir göstergesi olarak değerlendirilir, maddelerin bireyleri ölçülen davranış bakımından ne derece ayırt ettiğini gösterir (Büyüköztürk, 2011:171-172).

Tüm maddeler için madde-toplam korelasyonlarının 0,20-0,51 arasında değiştiği ve tüm $t$ değerlerinin anlamlı $(p<0,01)$ olduğu görülmektedir. Cronbach's Alpha değeri de 0,87 olarak bulunmuştur. $\mathrm{Bu}$ sonuçlar, ölçekteki maddelerin güvenirliklerinin yüksek olduğu, yöntemsel yeterlikler bakımından denekleri ayırt ettikleri ve aynı davranışı ölçmeye yönelik maddeler oldukları şeklinde yorumlanabilir. 


\section{F.Ü. Sosyal Bilimler Dergisi 2014-24/2}

\subsection{ARAŞTIRMA BULGULARININ DEĞERLENDİRILMESİ}

\section{Demografik Özelliklerine İlişkin Bulgular}

Tablo 1. Cevaplayıcıların demografik özelliklerine göre dağılımı

\begin{tabular}{|l|l|l|l|}
\hline Demografik Özellik & Gruplar & $\mathrm{N}$ & $\%$ \\
\hline \multirow{4}{*}{ Cinsiyet } & Bay & 266 & 69,3 \\
\cline { 2 - 4 } & Bayan & 118 & 30,7 \\
\hline \multirow{5}{*}{ Yaşitim } & $18-30$ & 184 & 47,9 \\
\cline { 2 - 4 } & $31-40$ & 127 & 33,1 \\
\cline { 2 - 4 } & $41-50$ & 60 & 15,6 \\
\cline { 2 - 4 } & 51 ve üzeri & 13 & 3,4 \\
\hline \multirow{4}{*}{ Meslek } & İlköğretim & 15 & 3,9 \\
\cline { 2 - 4 } & Lise & 111 & 28,9 \\
\cline { 2 - 4 } & Üniversite & 234 & 60,9 \\
\cline { 2 - 4 } & Yüksek lisans & 24 & 6,3 \\
\hline Toplam & İnşaat & 66 & 17,2 \\
\cline { 2 - 4 } & Memur & 234 & 60,9 \\
\cline { 2 - 4 } & Diğer & 84 & 21,9 \\
\hline
\end{tabular}

Araştırmaya katılan 384 cevaplayıcının 266'sı erkek, 118'i kadındır. 184'ü 18-30 yaş, 127'si 31-40 yaş, 60'ı 41-50 yaş aralığında, 13'ü 51 yaş ve üzerindedir. Cevaplayıcıların 15'i ilköğretim, 111'i lise, 234'ü üniversite, 24'ü yüksek lisans eğitim düzeyindedir. Cevaplayıcıların 66'sı inşaat sektöründe, 234'ü memur, 84'ü diğer (serbest meslek) meslek sahibidir.

Tablo 2. İnternet Bankacılığında Önem Verilen Kriterlerin Katılım Bankalarında Yoğun Olarak Gerçekleştirilen İletișim Kanalı Değişkenine Göre T-Testi Sonuçları

\begin{tabular}{|c|c|c|c|c|c|c|}
\hline & İletişim Kanalı & $\mathrm{N}$ & $\bar{X}$ & SS & $\mathrm{t}$ & $\mathrm{p}$ \\
\hline \multirow{2}{*}{ Web sitesinin güvenirliği } & Şube & 165 & 1,20 & 0,58 & 0,22 & 0,83 \\
\hline & Elektronik kanallar & 219 & 1,19 & 0,56 & & \\
\hline \multirow{2}{*}{ Web sitesinin kullanım kolaylığı } & Şube & 165 & 1,43 & 0,66 & $-0,44$ & 0,66 \\
\hline & Elektronik kanallar & 219 & 1,46 & 0,69 & & \\
\hline \multirow{2}{*}{ Web sayfasının yüklenme hızı } & Şube & 165 & 1,52 & 0,79 & 1,43 & 0,15 \\
\hline & Elektronik kanallar & 219 & 1,42 & 0,66 & & \\
\hline \multirow{2}{*}{ Yapılan işlemin düşük maliyetli olması } & Şube & 165 & 1,38 & 0,69 & $-1,37$ & 0,17 \\
\hline & Elektronik kanallar & 219 & 1,49 & 0,80 & & \\
\hline \multirow{2}{*}{ 7/24 hizmet alınabilmesi } & Şube & 165 & 1,47 & 0,79 & 2,20 & 0,03 \\
\hline & Elektronik kanallar & 219 & 1,31 & 0,64 & & \\
\hline \multirow{2}{*}{ Bürokratik işlemin az olması } & Şube & 165 & 1,66 & 0,86 & 0,14 & 0,89 \\
\hline & Elektronik kanallar & 219 & 1,65 & 0,88 & & \\
\hline \multirow{2}{*}{ Web sitesinin sürekli yenilenmesi } & Şube & 165 & 1,81 & 0,93 & $-0,60$ & 0,55 \\
\hline & Elektronik kanallar & 219 & 1,87 & 1,04 & & \\
\hline \multirow{2}{*}{$\begin{array}{l}\text { İnternetten yaptığınız işlem ile ilgili } \\
\text { bilgilendirme SMS almanız. }\end{array}$} & Şube & 165 & 1,50 & 0,76 & $-1,67$ & 0,10 \\
\hline & Elektronik kanallar & 219 & 1,66 & 0,99 & & \\
\hline \multirow{2}{*}{$\begin{array}{l}\text { Ana kullanıcıya bağlı alt kullanıcıların } \\
\text { belirlenerek farklı düzeylerde yetkilendirilmesi }\end{array}$} & Şube & 165 & 1,87 & 1,02 & \multirow{2}{*}{$-1,34$} & \multirow{2}{*}{0,18} \\
\hline & Elektronik kanallar & 219 & 2,02 & 1,08 & & \\
\hline
\end{tabular}
$\mathrm{p}<0,052,14$

Web sitesi güvenirliğine verilen önemin cevaplayıcıların katılım bankalarında yoğun olarak gerçekleştirdikleri iletişim kanalı değişkenine göre anlamlı farklılık göstermediği bulgusu elde edilmiştir $(\mathrm{t}=0,22 \mathrm{p}>0,05)$.

Araştırmanın birinci hipotezi "Katılım Bankalarında web sitesinin güvenirliği ile müşterilerin iletişim kanalı seçimi arasında istatistiksel bir bağlantı vardır." Hipotezi $\% 5$ anlamlılık düzeyinde $\mathrm{p}=0,83$ olduğu için $(\mathrm{p}>0,05)$ hipotez kabul edilmemiştir. 
Web sitesinin kullanım kolaylığına verilen önemin cevaplayıcıların katılım bankalarında yoğun olarak gerçekleştirdikleri iletişim kanalı değişkenine göre anlamlı farklılık göstermediği bulgusu elde edilmiştir ( $\mathrm{p}=0,66 \mathrm{p}>0,05)$.

Web sayfasının yüklenme hızına verilen önemin cevaplayıcıların katılım bankalarında yoğun olarak gerçekleştirdikleri iletişim kanalı değişkenine göre anlamlı farklılık göstermediği bulgusu elde edilmiştir $(\mathrm{p}=0,15 \mathrm{p}>0,05)$.Yapılan işlemin düşük maliyetli olmasına verilen önemin cevaplayıcıların katılım bankalarında yoğun olarak gerçekleştirdikleri iletişim kanalı değişkenine göre anlamlı farkl1lık göstermediği bulgusu elde edilmiştir ( $\mathrm{p}=0,17 \mathrm{p}>0,05)$.

Araştırmanın ikinci hipotezi "Katılım Bankalarında 7/24 hizmet alınması müşterilerin iletişim kanalı seçiminde istatistiksel olarak anlamlı ilişki vardır." Şeklinde ifade edilen hipotezi $p=0,03$, $p<0,05$ olduğu için kabul edilmiştir. 7/24 hizmet alınabilmesine verilen önemin cevaplayıcıların katılım bankalarında yoğun olarak gerçekleştirdikleri iletişim kanalı değişkenine göre anlamlı farkl111k gösterdiği bulgusu elde edilmiştir $(\mathrm{t}=2,20 \mathrm{p}<0,05) .7 / 24$ hizmet alınabilmesine yoğun olarak şubeden işlem gerçekleştiren cevaplayıcıların verdiği önem puanları $(1,47)$ yoğun olarak elektronik kanallardan işlem gerçekleştiren cevaplayıcıların verdiği önem puanından $(1,31)$ anlamlı düzeyde daha yüksektir. Katılım bankaları müşterileri 7/24 hizmet alınmasının, banka ile yoğun olarak gerçekleştirdikleri iletişim kanalı olan şube veya elektronik kanallardan önemli olduğu sonucu elde edilmiştir.

Bürokratik işlemlerin az olmasına verilen önemin cevaplayıcıların katılım bankalarında yoğun olarak gerçekleştirdikleri iletişim kanalı değişkenine göre anlamlı farklılık göstermediği bulgusu elde edilmiştir ( $\mathrm{p}=0,89 \mathrm{p}>0,05)$.

Web sitesinin sürekli yenilenmesine verilen önemin cevaplayıcıların katılım bankalarında yoğun olarak gerçekleştirdikleri iletişim kanalı değişkenine göre anlamlı farklılık göstermediği bulgusu elde edilmiştir ( $\mathrm{p}=0,55 \mathrm{p}>0,05)$.

İnternetten yapılan işlem ile ilgili bilgilendirme SMS'i almaya verilen önemin cevaplayıcıların katılım bankalarında yoğun olarak gerçekleştirdikleri iletişim kanalı değişkenine göre anlamlı farklılık göstermediği bulgusu elde edilmiştir ( $p=0,10 p>0,05)$.

Ana kullanıcıya bağlı alt cevaplayıcıların belirlenerek farklı düzeylerde yetkilendirilmeye verilen önemin $\mathrm{k}$ cevaplayıcıların katılım bankalarında yoğun olarak gerçekleştirdikleri iletişim kanalı değişkenine göre anlamlı farklılık göstermediği bulgusu elde edilmiştir $(p=0,18 p>0,05)$.

Tablo 3. İnternet Bankacılığında Önem Verilen Kriterlerin Cinsiyet Değişkenine Göre T-Testi Sonuçları

\begin{tabular}{|c|c|c|c|c|c|c|}
\hline & Cinsiyet & $\mathrm{N}$ & $\overline{\mathrm{X}}$ & SS & $\mathrm{t}$ & $\mathrm{p}$ \\
\hline \multirow{2}{*}{ Web sitesinin güvenirliği } & Bay & 266 & 1,19 & 0,57 & $-0,05$ & 0,96 \\
\hline & Bayan & 118 & 1,19 & 0,57 & & \\
\hline \multirow{2}{*}{ Web sitesinin kullanım kolaylığı } & Bay & 266 & 1,43 & 0,64 & $-0,68$ & 0,50 \\
\hline & Bayan & 118 & 1,48 & 0,75 & & \\
\hline \multirow{2}{*}{ Web sayfasının yüklenme hızı } & Bay & 266 & 1,43 & 0,70 & $-1,17$ & 0,24 \\
\hline & Bayan & 118 & 1,53 & 0,75 & & \\
\hline \multirow{2}{*}{ Yapılan işlemin düşük maliyetli olması } & Bay & 266 & 1,38 & 0,69 & $-2,31$ & $\mathbf{0 , 0 2}$ \\
\hline & Bayan & 118 & 1,58 & 0,88 & & \\
\hline \multirow{2}{*}{ 7/24 hizmet alınabilmesi } & Bay & 266 & 1,35 & 0,67 & $-1,05$ & 0,29 \\
\hline & Bayan & 118 & 1,43 & 0,80 & & \\
\hline \multirow{2}{*}{ Bürokratik işlemin az olması } & Bay & 266 & 1,61 & 0,86 & $-1,51$ & 0,13 \\
\hline & Bayan & 118 & 1,75 & 0,89 & & \\
\hline \multirow{2}{*}{ Web sitesinin sürekli yenilenmesi } & Bay & 266 & 1,89 & 1,04 & 1,37 & 0,17 \\
\hline & Bayan & 118 & 1,74 & 0,88 & & \\
\hline \multirow{2}{*}{$\begin{array}{l}\text { İnternetten yaptığınız işlem ile ilgili } \\
\text { bilgilendirme SMS almanız. }\end{array}$} & Bay & 266 & 1,59 & 0,87 & $-0,15$ & 0,88 \\
\hline & Bayan & 118 & 1,60 & 0,97 & & \\
\hline \multirow{2}{*}{$\begin{array}{l}\text { Ana kullanıcıya bağlı alt kullanıcıların } \\
\text { belirlenerek farklı düzeylerde yetkilendirilmesi }\end{array}$} & Bay & 266 & 1,97 & 1,06 & 0,29 & 0,77 \\
\hline & Bayan & 118 & 1,93 & 1,04 & & \\
\hline
\end{tabular}




\section{F.Ü. Sosyal Bilimler Dergisi 2014-24/2}

Web sitesi güvenirliğine verilen önemin cevaplayıcıların cinsiyetine göre anlamlı farklılık göstermediği bulgusu elde edilmiştir ( $\mathrm{p}=0,96 \mathrm{p}>0,05)$.

Web sitesinin kullanım kolaylı̆̆ına verilen önemin cevaplayıcıların cinsiyetine göre anlamlı farkl11lk göstermediği bulgusu elde edilmiştir $(p=0,50 p>0,05)$.

Web sayfasının yüklenme hızına verilen önemin cevaplayıcıların cinsiyetine göre anlamlı farklılık göstermediği bulgusu elde edilmiştir $(p=0,24 p>0,05)$.

Ancak araştırmanı üçüncü hipotezi "Katılım Bankalarında İnternet Bankacılığında yapılan işlemin düşük maliyetli olması ile müşterilerin cinsiyeti arasında istatistiksel bir ilişki vardır." Hipotezi doğrulanmıştır. Bir başka ifade ile katılım bankaları ile çalışan bayan müşterilerin yapılan işlemin düşük maliyetli olması konusunda daha hassas olduğu ortaya konulmaktadır.

Yapılan işlemin düşük maliyetli olmasına verilen önemin cevaplayıcıların cinsiyetine göre anlamlı farklılık gösterdiği bulgusu elde edilmiştir $(\mathrm{p}=0,02 \mathrm{p}<0,05)$. Yapılan işlemin düşük maliyetli olmasına bayan cevaplayıcıların verdiği önem puanları $(\overline{\mathrm{X}}=1,58)$ bay cevaplayıcıların verdiği önem puanından $(\bar{X}=1,38)$ anlamlı düzeyde daha yüksektir. Katılım bankalarında bayan müşterilerin yapılan işlemlerin maliyetinin düşük olması konusunda erkeklere göre daha hassas oldukları bu da bayanların fiyata karşı daha duyarlı olduklarını ortaya koymaktadır.

$7 / 24$ hizmet alınabilmesine verilen önemin cevaplayıcıların cinsiyetine göre anlamlı farklılık göstermediği bulgusu elde edilmiştir ( $\mathrm{p}=0,29 \mathrm{p}>0,05)$.

Bürokratik işlemlerin az olmasına verilen önemin cevaplayıcıların cinsiyetine göre anlamlı farklılık göstermediği bulgusu elde edilmiştir ( $p=0,13 p>0,05)$.

Web sitesinin sürekli yenilenmesine verilen önemin cevaplayıcıların cinsiyetine göre anlamlı farkl11ık göstermediği bulgusu elde edilmiştir $(\mathrm{p}=0,17 \mathrm{p}>0,05)$.

İnternetten yapılan işlem ile ilgili bilgilendirme SMS 'i almaya verilen önemin cevaplayıcıların cinsiyetine göre anlamlı farklılık göstermediği bulgusu elde edilmiştir $(p=0,88 p>0,05)$. Yani her iki cinsiyet de internet üzerinden yapılan işlemlerde bilgilendirme SMS'si almayı istedikleri ortaya çıkmaktadır.

Ana kullanıcıya bağlı alt kullanıcıların belirlenerek farklı düzeylerde yetkilendirilmeye verilen önemin cevaplayıcıların cinsiyetine göre anlamlı farklılık göstermediği bulgusu elde edilmiştir $(\mathrm{p}=0,77 \mathrm{p}>0,05)$.

Kısaca hem bayların hem de bayanların katılım bankalarında internet bankacıllğında önem verilen kriterlerde çok fazla bir farklılık olmamasına rağmen, yapılan işlemlerin maliyetlerinin düşük olması noktasında bayanların yaklaşımının daha hassas olduğu ortaya konulmaktadır.

Tablo 4. İnternet Bankacılığında Önem Verilen Kriterlerin Eğitim Düzeyi Değişkenine Göre ANOVA Sonuçları

\begin{tabular}{|l|l|l|l|l|l|l|}
\hline \multicolumn{1}{|c|}{ Varyansın Kaynağ1 } & $\begin{array}{c}\text { Kareler } \\
\text { Toplam1 }\end{array}$ & \multicolumn{1}{|c|}{$\mathrm{sd}$} & $\begin{array}{c}\text { Kareler } \\
\text { Ortalamas } 1\end{array}$ & $\mathrm{~F}$ & $\mathrm{p}$ & Farkın Kaynağ \\
\hline Gruplararas1 & 1,63 & 3 & 0,54 & 1,69 & 0,17 & \\
\hline Gruplariçi & 122,11 & 380 & 0,32 & & & \\
\hline Toplam & 123,74 & 383 & & & & \\
\hline Gruplararas1 & 3,15 & 3 & 1,05 & 2,32 & 0,07 & \\
\hline Gruplariçi & 171,81 & 380 & 0,45 & & & \\
\hline Toplam & 174,96 & 383 & & & & \\
\hline Gruplararas1 & 5,05 & 3 & 1,68 & 3,33 & 0,02 & B-D \\
\hline Gruplariçi & 192,36 & 380 & 0,51 & & & C-D \\
\hline Toplam & 197,41 & 383 & & & & \\
\hline Gruplararas1 & 3,69 & 3 & 1,23 & 2,15 & 0,09 & \\
\hline Gruplariçi & 217,05 & 380 & 0,57 & & & \\
\hline Toplam & 220,74 & 383 & & & & \\
\hline Gruplararas1 & 4,47 & 3 & 1,49 & 2,98 & 0,03 & B-D \\
\hline Gruplariçi & 189,53 & 380 & 0,50 & & & \\
\hline
\end{tabular}


Katılım Bankalarında İnternet Bankacıllı̆g: Elazı $\check{g}_{\ldots}$

\begin{tabular}{|l|l|l|l|l|l|l|}
\hline Toplam & 194,00 & 383 & & & & \\
\hline Gruplararas1 & 9,73 & 3 & 3,24 & 4,41 & 0,00 & B-D \\
Gruplariçi & 279,21 & 380 & 0,73 & & & \\
\hline Toplam & 288,93 & 383 & & & & \\
\hline Gruplararas1 & 9,84 & 3 & 3,28 & 3,39 & 0,02 & B-D \\
\hline Gruplariçi & 367,47 & 380 & 0,97 & & & C-D \\
\hline Toplam & 377,31 & 383 & & & & \\
\hline Gruplararas1 & 5,85 & 3 & 1,95 & 2,43 & 0,06 & \\
\hline Gruplariçi & 304,96 & 380 & 0,80 & & & \\
\hline Toplam & 310,81 & 383 & & & & \\
\hline Gruplararas1 & 12,56 & 3 & 4,19 & 3,86 & 0,01 & C-D \\
\hline Gruplariçi & 411,69 & 380 & 1,08 & & & \\
\hline Toplam & 424,25 & 383 & & & & \\
\cline { 1 - 3 } \\
p $<0,05$
\end{tabular}

Web sitesi güvenirliğine verilen önemin cevaplayıcıların eğitim düzeyine göre anlamlı farklılık göstermediği bulgusu elde edilmiştir $\left(\mathrm{F}_{(3 ; 380)}=1,69 ; \mathrm{p}>0,05\right)$.

Web sitesinin kullanım kolaylığına verilen önemin cevaplayıcıların eğitim durumuna göre anlamlı farklılık göstermediği bulgusu elde edilmiştir $\left(\mathrm{F}_{(3 ; 380)}=2,32 ; \mathrm{p}>0,05\right)$.

Araştırmanın dördüncü hipotezi olan "Katılım Bankalarında web sitesinin yüklenme hızı ile müşterilerin eğitim düzeyi arasında istatistiksel bir bağlantı vardır." İfadesi $p=0,02 p<0,05$ olduğu için hipotez doğrulanmıştır. Farklı eğitim düzeyindeki kullanıcıların internet bankacılığında, internet sayfalarının yüklenme hızı farklılık göstermektedir. Web sayfasının yüklenme hızına verilen önemin cevaplayıcıların eğitim düzeyine göre anlamlı farklılık gösterdiği bulgusu elde edilmiştir $\left(\mathrm{F}_{(3 ; 380)}=3,33 ; \mathrm{p}<0,05\right)$. Web sitesinin hızlı yüklenmesine lise mezunu $(1,60)$ ve üniversite mezunu $(1,44)$ cevaplayıcıların verdiği önem puanları yüksek lisans mezunu cevaplayıcıların verdiği önem puanından $(1,17)$ anlamlı düzeyde daha yüksektir.

"Katılım Bankalarında web sitesinin sürekli yenilenmesi ile müşterilerin eğitim düzeyi arasında istatistiksel olarak anlamlı bir ilişki vardır." Şeklinde ifade edilen araştırmanın beşinci hipotezi, tablo 37'nin ilgili satırında $\mathrm{p}=0,02, \mathrm{p}<0,05$ nedeniyle hipotez kabul edilmiştir. Web sitesinin sürekli yenilenmesine verilen önemin cevaplayıcıların eğitim düzeyine göre anlamlı farkl1lık gösterdiği bulgusu elde edilmiştir $\left(\mathrm{F}_{(3 ; 380)}=3,39 ; \mathrm{p}<0,05\right)$. Web sitesinin sürekli yenilenmesine lise mezunu $(1,95)$ ve üniversite mezunu $(1,86)$ cevaplayıcıların verdiği önem puanları yüksek lisans mezunu cevaplayıcıların verdiği önem puanından $(1,33)$ anlamlı düzeyde daha yüksektir.

Yapılan işlemin düşük maliyetli olmasına verilen önemin cevaplayıcıların eğitim düzeyine göre anlamlı farkl1lık göstermediği bulgusu elde edilmiştir $\left(\mathrm{F}_{(3 ; 380)}=2,15 ; \mathrm{p}>0,05\right)$.

Kısaca internet bankacılığında önem verilen çeşitli kriterlere cevaplayıcıların eğitim düzeyine göre bazı farklılıklar gözükmektedir. Cevaplayıcıların eğitim düzeyleri internet bankacılığına bakış açılarında farklılık yaratmaktadır. Yüksek lisans mezunu cevaplayıcıların web sayfasının yüklenme hızını lise mezunu cevaplayıcılara göre daha önemsiz görmeleri bu farklılığı ortaya koymaktadır.

7/24 hizmet alınabilmesi, bürokratik işlemlerin az olması, web sitesinin sürekli yenilenmesi gibi kriterlere, lise ve üniversite mezunları daha önemli görmekte iken yüksek lisans mezunları bütün bunları önemsemeden internet bankacılığını kullandığı ortaya konulmaktadır.

\section{SONUÇ}

Bankaların uyguladıkları mevduat ve kredi faizlerinin İslâm'ın dininin yasakladığı faiz niteliğindedir. Bilindiği gibi borç faizi; ödünç, alım-satım veya başka her hangi bir sebepten zimmete geçen bir borca karş1lk ödenecek olan mal veya parada, belli bir vadeden dolayı şart kılınan fazlalıktır. Bankalar hem mudilerinden topladıkları mevduata belli bir vade karşılığında belli bir faiz ödemekte hem kredi kullandırdıkları müşterilerinden belli vade karşıllı̆ında yine belli oranlarda faiz talep etmektedirler. 


\section{F.Ü. Sosyal Bilimler Dergisi 2014-24/2}

Katılım bankalarında ise faiz ilişkilerine yer verilmez. Paranın faizle borca verilmesi de söz konusu değildir. Katılım bankaları halktan kâr ortaklığı esasına göre fon toplar, bu fonları üçüncü kişilerle ortaklık kurmak veya alım-satım yapmak suretiyle değerlendirir ve elde edilen kârın \% 20'sini kendisine ayırdıktan sonra kalan \% 80’i de mudilerine dağıtır (Özsoy, 2012,86)

Katılım Bankacılığının 1980 sonrası ülkemizdeki hızlı gelişimi ve faizsiz bankacılık ihtiyacı duyan müşteri portföyünün varlığı Katılım Bankalarının hızla büyümesine neden olmuştur. Katılım bankalarının faizsiz bankacılık yapmaları faiz kavramının İslam hukukunda yasak olması, çeşitli tacir topluluklarının bu bankalar ile yoğun şekilde çalışmasına neden olmaktadır. Türkiye'nin 1980 sonrası dışa açılımı yabancı sermaye girişi ile birlikte yabancı menşeli bankaların artmasına ve sektörde rekabetin artmasına yol açmıştır. Ülkelerin yönetim ve sosyal faktörlerine göre faizsiz bankacılığın tüm sektör içindeki payları değişik oranlarla ifade edilmektedir. Ülkemizde bu oran \%5 seviyelerindeyken, Malezya'da İslami bankacılığın büyüklüğü sektörün \%20'si, İran'da \%40, Suudi Arabistan'da \%35 düzeylerinde olup ülkelerin sosyal faktörlerine göre gelişme göstermişlerdir.

Faizsiz finans sistemine ait ürünlerin dünya genelinde 1970 yıllardan itibaren yaklaşı 75 ülkede kullanıldığı düşünülmektedir. Bu ülkeler geçmişte ağırlıklı olarak Orta Doğu ve Güneydoğu Asya'da yoğunlaşmışken, günümüzde İngiltere, Almanya, ABD gibi batı ülkelerinde de faizsiz finans sistemine ait ürünlerin hızla yayılmaya başladığ 1 görülmektedir. 1970'li yıllardan itibaren gelişme gösteren İslami Finans Sistemi'nin, 2000'li yıllarla birlikte uluslararası finansal sistemle de bütünleşme yolunda önemli ilerlemeler sağladığ1 ve günümüzün gereği olarak farklı istek ve ihtiyaçlara cevap verebilecek araç, yöntem ve hizmetler geliştirebildiği görülmektedir.

Ülkemiz nüfusunun \%98'nin Müslüman olması nedeniyle, İslam hukukuna göre faaliyet gösteren bir sektörün gelişmesi ve büyümesi yeterli enstrümanların sunumu mümkün hale gelecektir. Ülkemizde 2005 yılında yapılan düzenlemelerle bu bankalarında 5411 sayılı Bankacılık Kanunu'na tabi olması ve bu bankalardaki fonların da diğer bankalarda olduğu gibi Tasarruf Mevduatı Sigorta Fonu güvencesi altına alınması, 2005 yılında toplam 290 şubeye sahip Katılım Bankalarının 2012 sonu itibariyle 829 şubeye ulaşmalarına neden olmuştur.

Sektörün gelişmesi sürekli yeni enstrümanların devreye sokulması, keza gelişen bilgi teknolojilerine uyum sağlamakla olacaktır. Sektör için bilgi teknolojilerinin başında internet bankac1lığı gelmektedir. Çünkü, bugün bir çok bankada müşteriler, banka şubesine gitmeden bütün işlemlerini gerçekleştirmektedirler.

Çalışmamızda Katılım Bankalarında internet bankacılığına müşterilerin yaklaşımı incelemeye çalışılmıştır. Günümüz bankacılığında, internet bankacılı̆̆ında bir çok bankanın ve müşterilerinin yaşadığı önemli sorun olan güvenlik sorunu, hackerlerin müşteri şifrelerini kırmaları büyük maddi kayıplara neden olmaktadır. Araştırmanın ilk hipotezi olan Katılım Bankalarında web sitesinin güvenirliği nedeniyle müşterilerin elektronik kanalları tercih etmemeleri arasında ilişki aranmış ancak hipotez kabul edilmemiştir. Yani Katılım bankaları müşterilerin şube veya elektronik kanallar aracılığıyla bankaları ile iletişime geçmeleri, web sitelerinin güvenlik sorunundan kaynaklanmadığ 1 ortaya konulmaktadır. Bu da Katılım bankalarının bir çok konuda olduğu gibi internet bankacılığında da kuralcı ve güvenli bir yapıya sahip olduğunu göstermektedir.

Yine bankacılık sektöründe önemli enstrümanlardan biri olan 7/24 hizmet alınması hem müşterilerin ihtiyaçları mekan ve zaman farklılığı gözetilmeksizin karşılanabilmekte hem de bankaların hizmet maliyetlerinin azalmasına, neden olmaktadır. Araştırmaya konu olan ikinci hipotez katılım bankalarında 7/24 hizmet alınması ile müşterilerin iletişim kanalı seçimini etkilemesidir. Kabul edilen hipotezin katılım bankaları müşterilerinin mekan ve zaman sınırlaması olmadan hizmet almak istediklerini göstermektedir. Bilgi teknolojileri çağının yaşandığı günümüzde, iş hayatında zaman kavramı çok önemli bir olgu olmuştur. Bu da katılım bankaları müşterilerinin internet bankacılığ 1 iletişim kanalını seçmelerinin önemli nedenlerinden birinin bankadan 7/24 hizmet almaları olarak değerlendirilmektedir. 
Çalışmada, İnternet bankacılığ işlem maliyetleriyle katılım bankaları müşterilerinin cinsiyetleri arasında bir ilişki bulgulanmıştır. Bayan müşterilerin internet bankacılığındaki fiyata verdikleri tepkinin, erkek müşterilere göre daha esnek olduğu, bunun da bayanların sosyal yapısı ile açıklanabileceği ortaya konulmaktadır.

Araştırmanın son hipotezinde ise katılım bankası müşterilerin eğitim düzeyleri ile web sitelerinin yüklenme hızı web sitelerinin sürekli yenilenmesi arasındaki ilişki incelenmeye çalışılmıştır. Müşterilerin eğitim düzeyleri yükseldikçe web sitelerinin yüklenme hızı ve web sitelerinde yapılan yeniliklerin önemsenmediği ortaya konulmaktadır.

\section{KAYNAKÇA}

Akgeyik, T., ve Yavuz, A., (2008), Türk Bankacılık Sektöründe Yabancılaşma: Risk mi Fırsat mı? İTO Yayınları 50, İstanbul

Aras, N.O., Öztürk, M., (2011), "Reel Ekonomiye Katkıları Bakımından Katılım Bankalarının Kullandırdığı Fonların Analizi”, Ekonomi Bilimleri Dergisi Cilt 3, No 2, ISSN: 1309-8020 (Online.

Aktepe, İshak E. (2010), İslam Hukuku Çerçevesinde Finansman ve Bankacılık, İstanbul.

Aslan İ., (1998), İnternet El Kitabı, Sistem Yayıncılık, İstanbul.

Atlı, Y., (2013), Bankacılık Sektöründe E-Pazarlama Uygulamaları Elazığ İlindeki Katılım Bankaları Müşterileri Üzerine Bir Araştırma (Fırat Üniversitesi, Sosyal Bilimler Enstitüsü, Yayınlanmamış Yüksek Lisans Tezi) Elazığ.

Battal, A. (2004), Bankalar Kanunu Şerhi Sorularla Banka Hukuku, Ankara: Gazi Kitapevi.

Büyüköztürk, Ş., (2011), Sosyal Bilimler İçin Veri Analizi El Kitabı. Pegem Akademi, Ankara.

Çınar R., Ercis A., (1993), “Genç Pazarın Banka Hizmetlerini Tercihleri Üzerine Bir Saha Araştırması”, Pazarlama Dünyası, VII, 37.

İnce M., (1999), Elektronik Ticaret: Gelişme Yolundaki Ülkeler İçin İmkanlar ve Politikalar, İktisadi Sektörler ve Koordinasyon Genel Müdürlüğü, Hukuki Tedbirler ve Kurumsal Düzenlemeler Dairesi Başkanlığı, Ankara.

Işkın Seyit A., (2010), Türk Bankacılık Sisteminde Alternatif Dağıtım Kanalları (Elektronik Bankacılık) Hizmetlerinin Riskleri ve Denetimi (Marmara Üniversitesi Bankacılık ve Sigortacılık Enstitüsü Yayınlanmamış Yüksek Lisans Tezi) İstanbul. Ankara.

Nakip, M., (2003) Pazarlama Arastırmaları Teknikler ve SPSS Destekli Uygulamalar, Seçkin Kitabevi,

Öztürk,S. , (2009), Hizmet Pazarlaması. 8. Baskı Eskişehir, Ekin Basım Yayın Dağıtım, Eskişehir.

Özsoy, İ., (2012), Türkiye’de Katılım Bankacılığı, Türkiye Katılım Bankaları Birliği, İstanbul.

Parasız, İ.M., (1992), Para, Banka ve Finansal Kuruluşlar, Ezgi Kitapevi Yayınevi, Bursa. No:224.

Saka, T., (2001), Türk Bankacılık Sektöründe Bilgi Teknolojileri Denetimi, TBB Yayınları, İstanbul,

Şimşek, B., (2006), Katılım Bankalarında Hizmet Kalitesinin Ölçülmesi ve Örnek Bir Uygulama (Gazi Üniversitesi Eğitim Bilimleri Enstitüsü. Yayınlanmamış Yüksek Lisans Tezi), Ankara.

Tarlan, S., (1986), Tarihte Bankacılık, Ankara.

Uslu, İ., "Küresel Pazar ve Elektronik Ticaret", http://www.makalem.com/Search/ArticleDetails.asp ?bWhere=true\&nARTICLE id=3804 adresinden, (Erişim 2012)

Yazıcıŏ̆lu, Y. ve Erdoğan, S. , Spss Uygulamalı Bilimsel Araştırma Yöntemleri. Detay Yayıncılık, Ankara, 2004

http://www.tbb.org.tr/tr/ (Erişim Tarihi 22.12.2012) 
